\title{
Image of Africa in the Linguistic Worldview of Modern Russian People
}

\author{
Natalia Shershukova ${ }^{1}$ Yulia Pogrebnyak ${ }^{2, *}$ Daria Vaganova ${ }^{1}$ \\ ${ }^{1}$ Military Institute (Engineering and Technical) of Military Academy of Material and Technical Support named \\ after General A.V. Khrulev of the Ministry of Defense of the Russian Federation, Saint Petersburg, Russian \\ Federation \\ ${ }^{2}$ Comenius University, Bratislava, Slovakia \\ *Corresponding author. Email: pyuma@yandex.ru
}

\begin{abstract}
In this article the notional, figurative and evaluative components of the concept "Africa" are described as they are introduced in anecdotes in contemporary Russian culture. The analysis of anecdotes about Africa shows that the concept under consideration stands at the periphery of Russian people's world picture and has mostly a negative evaluative component. Africa is considered by modern Russian people as an interesting, unusual, but very dangerous place to live. In our opinion, the negative assessment of the concept "Africa" by modern Russian people is mainly due to the idea of Africa as an "alien", distant world, opposed to "their own world", close and native.
\end{abstract}

Keywords: Geographical concept, Anecdote, Linguistic culture, Evaluative component, Africa.

\section{INTRODUCTION}

Currently, much attention is paid to the problems of cognitive linguistics and linguistic cultural studies due to the increased interest of scientists to the problem of human individuality, the self-perception of a person as a representative of his/her people. The study of language personality, language picture of the world, language consciousness, its components, etc. is extremely important today.

The object of consideration in this article is the language units that reflect the image of Africa in the linguistic consciousness of the Russian people. The concept "Africa" in the Russian language consciousness, in our opinion, has not yet received the necessary development, which makes the research topic essential. Despite the processes of globalization, the emergence of a common Internet space, Africa still appears to the representatives of modern Russian linguistic culture as something complex, unusual and new.

The Russian people have a somewhat blurred image of Africa, which is formed mainly by their reading works of fiction dedicated to Africa, studying material in the school curriculum, getting acquainted with the materials of the media, cinema, popular science literature, self-education, and contacts with the inhabitants of Africa.

\section{MAIN FEATURES OF GEOGRAPHICAL CONCEPTS}

Being a multidimensional mental formation, the concept has three aspects - notional, figurative and evaluative. The notional side of the concept is the fixation of the concept in the language, its designation, description, features, comparative characteristics of this concept in relation to other concepts, since concepts do not exist in isolation. The image side is the visual, auditory, tactile and other characteristics of objects, phenomena, and events reflected in our consciousness. The evaluative side of the concept is the importance of this mental formation for both the individual and the collective. [1].

The correlation of the concept with a certain amount of knowledge allows us to talk about its field structure. Field organization involves the allocation of two parts - the core and the periphery. The core of the conceptual structure is correlated with the conventional, i.e., dictionary meanings of 
the lexical objectifiers of the concept. In the case of a rather complex semantic organization of words, it is possible to divide the core into segments. The periphery of the concept reflects subjective experience, various pragmatic components of units, connotations and associations arising from the mental representations of a given society or collective.

Lexicographic sources are presented as material for the reconstruction of the concept's nuclear zone, and texts are the best way to open access to the study of the individual's subjective representations that form the periphery of the concept. The study of cultural concepts is usually closely related to the study of texts in which these concepts are fixed and verbalized as a reflection of national culture and national consciousness.

Linguistic analysis of texts allows us to identify a set of lexical means that actualize conceptual meanings. When considering texts of different time periods, it becomes possible to determine the specifics of sets of lexical representatives at different time stages of the concept's existence. The comparison of the identified lexical means can serve as a kind of basis for observing changes, transformations of the concept, since the transformation of the mental essence is manifested in the ways of its linguistic objectification.

The concept of "Africa" belongs to the category of geographical. V. N. Kaluzkov believes that a geographical concept can be any place associated with a certain territory.

Geographical concepts get their names within a certain culture and have images that are stable within this culture, which manifest themselves in the form of associations, historical legends, proverbs, and sayings, and the range of images associated with them can be different.

Structurally, any geographical concept consists of three layers - information-image, onomastic (naming) and territorial basis.

Thus, as a collective concept, it reflects a toponym and a certain territory, place.

Thus, a geoconcept refers to any place that is significant for a particular community and has a stable image.

The correlation of the geographical concept with a specific territory is of great importance.

On the one hand, a geoconcept is the result of conceptualizing a territory. At the same time, geoconceptualization is understood as the process of natural historical development of space (its transformation, comprehension, mythologization) in the culture of the people. These geoconcepts are then transmitted through the education and upbringing systems. In the course of conceptualization, certain qualities and characteristics of the territory are absolutized and become dominant.

On the other hand, a geoconcept is a product of territory conceptualization. Geoconceptualization refers to the process of conscious constructive construction of new meanings of space and its geographical images.

Geographical concepts of modern society are formed under the active influence of science, art, politics, and the media.

In accordance with the structure of the geographical concept, three levels of territory conceptualization can be distinguished - physical, onomastic, and mental.

Physical geoconceptualization is associated with the physical development of the territory and the subsequent consolidation of this fact in the cultural space.

At the onomastic level, geoconceptualization is carried out in the form of nomination or renomination of the territory [2].

The mental aspect of conceptualization requires its study in the framework of linguistic and cultural studies.

\section{REPRESENTATION OF THE CONCEPT "AFRICA" IN EXPLANATORY DICTIONARIES AND RUSSIAN LITERATURE} Africa.

The core of the concept "Africa" is the toponym

Africa is the second largest continent after Eurasia, bordered by the Atlantic Ocean to the west and the Indian Ocean to the east and south.

In ancient times, there was no single name for the entire continent, since it was not yet studied. The Greeks called the part of modern Africa known to them Libya (after the Libu or Livu tribes). The name Africa originally referred to a small area near the Phoenician city-state of Carthage (in the north of modern Tunisia), where the Afro tribes (meaning "cave dwellers") lived. After the conquest of Carthage, the Romans founded here the province of 
Africa after the name of these tribes. In the Middle Ages, the toponym gradually spread first to the entire northwestern part of the mainland, and then to the entire mainland [3].

F. V. Kuvshinov considers the topic of Africa on the material of Russian literature of the first third of the twentieth century. The researcher shows the dichotomous character or this concept (freedom/oppression, heaven/hell, exotic/banal, dream/ reality), its continuity, dependence on stereotypes. The popularity of this topic is explained by its schematics and templates, which made it possible to declare any ideological attitudes without an evidence base. As a result, Africa has become understood as a locus where anything can happen, and with which it is possible to associate various deviations of everyday life in Russia.

The theme of Africa in Russian literature is often associated with a number of motifs:

- 1. Africa as a place of collision of forces of good and forces of evil

The position is being developed that Africa is the place of the future battle between imperialism and capitalism, on the one hand, and communism and proletarian justice, on the other.

- 2. Africa as a banality

The stereotypical perception of Africa and the realities associated with it are noted by writers. The philistine perception of Africa in life was transferred to literature.

Undoubtedly, this happenes due to the image of Othello. The stereotype of violent, passionate Africans has firmly entered the everyday consciousness.

\section{- 3. Africa as a lost paradise and exotic}

In the works of N. S. Gumilyov, Africa receives the status of an exotic place, which can be compared, for example, with India in terms of the degree of strangeness and mystery.

- 4. Africa as a symbol of savagery/backwardness/poverty

Africa is not only a kind of paradise, but also a hell, a symbol of backwardness and savagery [4].

F. E. Ude notes that the image of Africa in the Russian language consciousness is formed at the expense of Africanisms, which include nonequivalent vocabulary, exoticism, phraseology describing African realities, proper names, as well as texts about the life of the peoples of Africa.
Perception of Africa by Russian people is based on the idea of Africa in Pushkin's novel "The Arap of Peter the Great", then this image is developed in the poetry of $\mathrm{N}$. Gumilyov, in the books for children of K. Chukovsky and other works of Russian literature.

The language consciousness of Russians reflects somewhat blurred, dispersed ideas about the inhabitants, culture, socio-economic development, and nature of Africa as a distant, exotic, and obscure continent.

Russian language consciousness formed the nuclear constitutions of the image of Africa in the pre-written era, then they were fixed in the Russian chronicles in the form of toponyms and a small number of appellatives (Africa, Afrikaner, Afrikaner, Egypt, Egyptian, Ethiopian, Nile, Pharaoh).

The Afrikanisms presented in the explanatory dictionaries of the Russian language can be divided into three main groups: 1) ethnonyms - the names of the tribes and peoples inhabiting the continent (Egyptians, Abyssinians, Moors, etc., as well as Negroes, Negroids, mulatto, mestizo), 2) the names of African animals (hippopotamus, gorilla, giraffe, zebra, etc.), 3) the names of plants typical of Africa (agave, banana, baobab, melon tree, coffee tree, cardamom, mango, etc.)

Media texts, due to the specifics of modern ideas about the content of information, reflect mainly a negative image of the Black Continent [5].

The influence of stereotypical ideas about Africa is reflected in folklore, resulting in a satirical and humorous genre - anecdote.

\section{REPRESENTATION OF THE CONCEPT "AFRICA" IN MODERN RUSSIAN ANECDOTES}

In modern Russian linguistic culture the image of Africa is verbally embodied almost only in anecdotes, which probably indicates the practical remoteness of the Russian language consciousness from this geographical concept, and its low significance for modern Russian people.

We have found only one phraseological unit with the word "Africa" in the Russian language: "(someone) is in Africa the same". For example, "A fool is also a fool in Africa", which means that a definition of a fool can not be changed, it is the same even in such remote place as Africa, fools exist everywhere, even in Africa. 
This phrase expresses such a component of meaning as "the great distance of Africa from Russia and the strong difference between the culture of Africa and the culture of Russia".

Also in modern Russian linguistic culture we have identified several stereotypical phrases assigned to Africa: "black" continent, the patrimony of Barmaley (bandit), "tanned" continent, which suggest such semantic components as:" dark skin color of Africans "and their "wildness".

The theme of the great geographical remoteness of Africa and Russia is also presented in anecdotes.

Where are you going?

To Africa.

That's the other way around.

What difference does it make to me? I won't make it anyway.

Also in the minds of modern Russian people the theme of "terrible heat", which is constant in Africa is reflected.

1. - Why do Africans choose a bigger wife?

- She casts a larger shadow.

2. In Africa, children are put in a corner for bad behavior, and in the shade for good behavior.

Another stereotype is presented in the minds of modern Russian people: there are a lot of wild animals in Africa.

You girls make me feel like I'm in Africa.

Why in Africa?

There are only crocodiles around.

Many people in Africa are below the poverty line, and the continent itself is rich: there is much oil, fertile land, gold. On this continent, there are developed countries that influence the world economic space. Like the rest of the world, Africa is committed to innovation. In Nigeria, Morocco, and South Africa, the automotive industry is established, not every European country can boast of this.

We can distinguish a whole group of anecdotes, united by the theme "poverty".

Storks bringing children to a poor African village try not to drop below 3 meters so as not to become a birthday dinner.
Within the topic "poverty", there is a separate subgroup of anecdotes that critically assesses the lack of drinking water in African countries.

1. In African schools, children who go to wet a duster are absent for weeks."

2. African schoolchildren brought the teacher to tears to drink.

Often, the lack of water is intertwined with another problem - the lack of medicines, the lack of proper medical support.

1. - Do you know why there are no pharmacies in Africa?

- Because you can't take the pills on an empty stomach.

Another group of anecdotes is related to the theme of savagery of morals, backwardness, wildness and passion of Africans.

1. - So, if earlier cannibals from the TumboYumbo tribe ate three or four foreign tourists in a year, then this year none.

- Now all hope is for Russian tourists who are hungry for last-minute tours.

2. - Just try to declare in Africa that you have good taste, and you will immediately be eaten.

In modern Russian anecdotes, the dark skin color of Africans receives a negative assessment.

- Why is my skin so dark?"

- Because in Africa, the sun is very active, white skin just can not stand it.

- Why do I live in Saratov then?

In the view of most Russians, any whiteskinned person with blond hair is a European. Any dark-skinned person is from Africa. To refute this statement, we can say that the Dutch settled in South Africa, and the French developed the wild jungles of Angola.

In the last 10 years, a group of jokes appeared, where the main character is the American actress Angelina Jolie. Adoption of African children is a popular practice for America and European countries. In humorous folk art even such a noble cause has a negative connotation. The humor is not based on the African parents, but on the "receiving" side.

For you, Angelina Jolie is the epitome of beauty and in Africa, she is a terrible dragon who takes children [6]. 
In our opinion, the evaluative component of the concept "Africa" has a negative connotation, because Russians imagine Africa as a "foreign world", opposed to "their own world".

Yu. N. Stepanov points out the inseparable connection of the concepts "friend - foe" with the self-consciousness of the people.

These concepts categorize the world, distinguishing "own " and "alien", "other" and organize the space of the ethnos, isolating the relevant features of their own and foreign people [7].

A. A. Konstantinova believes that for people the antonymous relations of "native" and "alien" emphasize the difference between the former and "own", but do not deny the right of "strangers" to "their own", even if "wrong" laws, customs and habits of foreigners do not coincide with cultural traditions of the representatives of native culture.

The pair "my own - alien" in explanatory dictionaries is represented by the following antonymic pairs: right - wrong; good - bad; righteous - sinful; pure - unclean; living - dead; human - non-human (animal, demonic); internal external.

Dictionaries also contain a chain of links that organize the space of "one's own" and "someone else's". These include: blood-related, family (clan); ethnic (people, nation); linguistic (language, dialect); confessional (faith) ties [8].

Another reason for the negative assessment of Africa, in our opinion, is the fact that an observer belonging to another culture, a carrier of other cultural traditions is always inclined to look at someone else's culture, language, national characteristics from a position of superiority, and therefore some features (especially very different from the features of his/her own culture), characteristic of representatives of another culture, he/she can regard as negative [9].

\section{CONCLUSION}

Analysis of modern Russian anecdotes has shown that the image of Africa for modern Russian people is on the periphery of their worldview due to the geographical distance of Africa from Russia and its low value significance for Russian mentality.

In the minds of modern Russian people, the geographical concept "Africa" is very vaguely represented as: an exotic country, physically, socially and culturally very different from Russia. In modern Russian linguistic culture the idea of the alienness of Africa and Africans is emphasized.

In the structure of the concept "Africa", one can distinguish such semantic components as: great geographical distance from Russia, constantly hot climate, hunger, poverty and lack of water; backwardness and wildness of the indigenous inhabitants of Africa, their dark skin color; the presence of dangerous exotic animals.

In a modern Russian anecdote, in general, a negative assessment of life in Africa is given in comparison with Russia. Africa is considered by modern Russian people as an interesting, unusual, but very dangerous place to live.

In our opinion, the negative assessment of the concept of "Africa" by modern Russian people is mainly due to the idea of Africa as an "alien", distant world, opposed to "their own world", close and native.

\section{AUTHORS' CONTRIBUTIONS}

Natalia Shershukova is responsible for the theoretical part of the article.

Daria Vaganova identified the main semantic components of the concept "Africa" on the basis of modern Russian anecdotes.

Yulia Pogrebnyak contributed to revising and editing the whole article.

\section{REFERENCES}

[1] Karasik V. I. Language circle: personality, concepts, discourse. - Volgograd: peremena, 2002. - $480 \mathrm{p}$.

[2] Kalutskov V. N. "Geoconcepts in regional studies". http://eng.regionalstudies.ru/journal/homejorn al/rubric/2012-11-02-22-16-38/168--1-r.html

[3] Basik, S. N. General toponymy/ S. N. Basik.Minsk : BSU, 2008. - 168 p.

[4] Kuvshinov F. The theme of Africa in Russian literature of the first third of the twentieth century. Bulletin of VSU. Series: philology. journalism. 2015. No. 2, pp. 45-49.

[5] Ude F. E. The image of Africa in the Russian language consciousness: dissertation ... candidate of Philological Sciences: 10.02.19. Volgograd, 2008. - 240 p. 
[6] Jokes about Africa. - URL: anekdotovmir.ru https://www.anekdotovmir.ru/anekdotypro/anekdoty-pro-russkix/anekdoty-pronegrov/anekdoty-pro-afriku/

[7] Stepanov, Yu. S. Constants. Dictionary of Russian Culture. Stepanov, Yu. S., Moscow: Russian Culture Languages School, 1997. 824 p.

[8] Konstantinova A. A. Conceptualization of the space of ethnonyms "my own - alien". - URL: https://www.elibrary.ru/item.asp?id=1768600 0

[9] Karaulov Yu. N. Russian language and language personality-Publishing house: LKI, URSS Editorial, 2010. - 264 p. 